\title{
Identification and Alignment of Regional Typological Differences by the Level of Development of the Banking Industry and the Intensity of Its Interaction with the Non-financial Sector of the Economy of Territories
}

\author{
Irina Viktorovna Taranova ${ }^{1}$, Ekaterina Leonidovna Putrenok ${ }^{2}$, Anzhelika Tagirovna Aydinova ${ }^{1} \&$ Timofei \\ Jurievich Cherepuhin ${ }^{1}$ \\ ${ }^{1}$ FGBOU VPO Stavropol State Agrarian University, Russian Federation \\ ${ }^{2}$ North-Caucasus Institute of Humanities and Technical Sciences, Russian Federation \\ Correspondence: Irina Viktorovna Taranova, FGBOU VPO Stavropol State Agrarian University, Mira Street, \\ 347, 355009, Stavropol, Russian Federation. E-mail: taranovairina@yandex.ru
}

Received: October 25, 2014 Accepted: December 13, 2014 Online Published: March 16, 2015

doi:10.5539/ass.v11n7p128 URL: http://dx.doi.org/10.5539/ass.v11n7p128

\begin{abstract}
The slowdown of economic development noticed on the national and regional levels has complex nature and multiple determinants. Currently, the Russian national banking regulator conducts active policy to reduce the number of unreliable entities in the banking industry in order to improve governance and transparency of banking activities in the regions. At the regional level, "gray" schemes of banking activities prevail, which ultimately affects the level of development of meso-economic systems, the dynamics and nature of their "drift" toward the use of informal mechanisms of economic development. Based on this, adoption of appropriate managerial decisions in the regional banking policy requires identifying not only the mesolevel specificity of the banking industry development, but also its role in the interaction with other sectors of the local economy. Verification of the hypothesis to be discussed about the fact that the multivariate empirical evaluation of the degree of development of the banking industry in regions and its territorially expansionist and addictive-convergent capacity in the intersectoral collaboration can be a significant information-analytical basis for the development and adjustment of the directions of regulatory and control measures in the banking industry at the regional level by the Central Bank of the Russian Federation, requires development of an appropriate methodology, which determines the significance of the work for the science and practice. Based on this, the goal of this research is to develop effective teaching approaches to the identification of interregional differences in the level of development of the banking industry and to formulate recommendations to eliminate the identified differentiation. As a result of solution of the raised logical and methodical problem, the recommendations of organizational, applied, and analytical nature regarding identification of interregional asymmetry in the degree of development of the banking industry of the local economy were substantiated, and the policy-targeted approaches to reduction of the identified differentiation were formulated.
\end{abstract}

Keywords: economy, region, the banking industry of the regional economy, cross-sectoral cooperation

\section{Introduction}

Retrospective experience of regional economic transformations points to the need for developing a system of financial and infrastructural drivers in the economic space (Postalyuk, 2006). Some of these economic producers are the entities of the banking industry of the regional economy, represented by both regional banks, and branches of national and supranational bank establishments. In this case, at providing regulatory impact at the regional level, it is important not only to comply with the criterion of necessity and sufficiency of quantitative indicators, but also to take into account the degree of convergence of the banking and industry-servicing sectors of the economy of the region.

Universal consequences of the economic crisis led to reduced availability of bank credit products provided to the entities of the secondary and tertiary sectors of the economy, and as a result, to slowdown of the production dynamics, escalation of unemployment, and reduction of the gross regional product growth rate. (Cipriani, 2006) 
In this context, to increase the relevance of the factual array at making regulatory decisions in the sphere of regional banking policy, it is necessary to solve the tasks of assessment of the current status and identification of the trends in the development of the banking industry of the region performed in the context of its interaction with other sectors of the meso-economic system.

In addition, in order to identify regional issues and build relevant situational profiles, the transition and implementation period in the implementation of the paradigm of "tough" regulation of the banking industry requires development of methodologies for exposing the interregional differences and building the regions typology based on the complex criterion of the banking industry development status and its interaction with other elements of the economic space of the region, which at the same time will be an effective tool in the regional strategic goal-setting.

\section{Methodology}

The research results were obtained using the methods and tools for collecting, processing, and economically interpreting the source information and empirical block; the exact study of the object and subject of the study was provided; the results of correct synthesis of the package of techniques and methods of economic research, the package of which was formed in accordance with the requirements of the system and spatial-economic approaches, as well as the evolutionary-turbulent and transitive-post-industrial economy, were used. It includes analysis and synthesis, techniques of quantitative and multi-dimensional estimation, theoretical and empirical systematization and generalization, the typological, graphic, and comparative methods, as well as the anamorphic representation of the reduced space of the original multi-dimensional data, keeping the main topographic and visualization properties of the object of study. This ensures uniformity and clarity of the developed methodological approaches, non-contradiction of the obtained methodological results to the theoretical assumptions of the theories of depolarized balanced development of the economic space. In addition, to support the program-development guidelines, the block-matrix and adaptive-selective approach was used, which assumes correlation of program activities with the selected types of areas by the level of development of the banking industry of the economy and by the efficiency of its interaction with the real sector. This allows for better targeted nature of the planned activities in comparison with the traditional approaches to regulation of the banking industry of the regions' economies.

\section{Results}

\subsection{Rationale for the System of Performance Indicators for the Multi-dimensional Comparisons}

The transformational-destructive phenomena in the economic space in the region of the South of Russia are in many respects determined by the uneven distribution of different kinds of resources and economic producers between the system-forming elements of sub-federal socio-economic systems, the mobility of spatial elements of the latter, which mobility follows the global trends. (Valliullin, 2009) Permanent monitoring of the parametrial characteristics of the processes of development of the banking industry and its interaction with various sectors of the regional economy targets diagnosing the concentration and intensification phenomena (Frankel, 1996; Sachs, 1996), which from the objectively relevant point allows approaching the problem of leveling the interregional asymmetry by the criterion of saturation of the economic area with financial and infrastructural elements.

In order to obtain relevant understanding of the degree of inter-regional polarization by the development of the banking industry and the intensity of its interaction with the real sector of the economy of territories, we consider it appropriate to apply integrated evaluation approaches based on ranking and using multi-dimensional comparisons of individual territories by the classical method of summing the points, adapted in the context of our study through the introduction of indicators that reflect the basic parameters of interaction between the banking industry and the real sector of the local economy. The less the sum of points is, the higher the concentration of banking institutions in the region and their interaction with the business structures across sectors are.

As the object of inter-regional comparative analysis, we selected regions of the North Caucasus Federal District (NCFD), where the economy is of agrarian type (Bobryshev, 2013; Tomilina, 2013; Sadkov, 2006), and as the indicative attributes, it is advisable to use the following indicators chosen by us as the most relevant ones from the point of reflection of the level of the banking industry development in its concentration aspect:

$A_{1}$ - The absolute index of the number of banking organizations operating in the region; $A_{2}-$ The number of branch offices of bank structures registered in the territory of the region; $A_{3}$ - The number of branches of banks from other regions; $\mathrm{A}_{4}-$ The index of development of the branch network of regional banks; $\mathrm{A}_{5}-$ The index of "expansion" of regional banks; $\mathrm{A}_{6}$ - the number of banking institutions and their branches per 100,000 people; 
$\mathrm{A}_{7}$ - The volume of financial resources per one credit institution; $A_{8}-$ The share of assets of the regional credit institutions in total assets of the banking system; $A_{9}$ - The share of deposits in the liabilities of commercial banks; $\mathrm{A}_{10}$ - The total profit (loss) of credit institutions in the region; $\mathrm{A}_{11}$ - The return on assets of regional banks.

The first block of the system of indicators of this methodical approach includes the relevant-consistent set of indicators to assess the parameters of interaction of the non-financial sector and the banking industry of the regional economy:

$\mathrm{B}_{1}$ - Investments in fixed assets; $\mathrm{B}_{2}$ - The share of bank loans in the investments in fixed assets; $\mathrm{B}_{3}$ - The share of bank loans in the gross regional product; $\mathrm{B}_{4}-$ The index of physical saturation of the region with banking services (by assets); $\mathrm{B}_{5}-$ The index of financial saturation of the region with banking services (loans); $\mathrm{B}_{6}-$ The total volume of outstanding loans of the real sector of the economy of the region;

Such a dual combination of indicators for a comparative multivariate analysis makes it possible, in comparison with the existing approaches, to conduct comprehensive diagnostics of regions by the two polymer characteristics: the level of development of the banking industry and the intensity of its interaction with the real sector of the economy of territories.

The methodical logic of the sum-of-points method involves preliminary ranking of all regions by each indicator, characterizing the studied polymer phenomenon (Rykova, 2008). In this case, the highest numerical ranks are awarded to the best values of the totality of the observed units. As the amount of points by all the indicators under review has been calculated, the opportunity to set the aggregate ranks of regions according to their level of development is provided.

\subsection{Rating Calculations and Classification of the Typology of Regions}

In accordance with the proposed methodological approach, the thresholds for rank regions in polar areas based on "cross-border segmentation» were determined (Erlander, 1980) within the framework of evaluation of the level of development of the banking industry and the intensity of its interaction with the real sector of the territories economy. At that, when awarding the ratings, we took into account the arithmetic mean for the five-year period for each indicator, which improves the representativeness and validity of the findings (Table 1).

Table 1. Local and total ranks of the NCFD regions by the level of development of the banking industry and the intensity of its interaction with the real sector of the economy of territories

\begin{tabular}{ccccccc}
\hline Index & \multicolumn{7}{c}{ Regions of the NCFD } \\
\cline { 2 - 7 } & SR & RNO & KCR & KBR & RI & RD \\
\hline $\mathrm{A}_{1}$ & 2 & 3 & 5 & 3 & 6 & 1 \\
$\mathrm{~A}_{2}$ & 1 & 5 & 4 & 2 & 2 & 6 \\
$\mathrm{~A}_{3}$ & 1 & 3 & 5 & 3 & 6 & 2 \\
$\mathrm{~A}_{4}$ & 4 & 3 & 5 & 2 & 6 & 1 \\
$\mathrm{~A}_{5}$ & 1 & 5 & 4 & 2 & 2 & 6 \\
$\mathrm{~A}_{6}$ & 3 & 2 & 4 & 5 & 6 & 1 \\
$\mathrm{~A}_{7}$ & 1 & 3 & 5 & 2 & 6 & 4 \\
$\mathrm{~A}_{8}$ & 6 & 2 & 4 & 3 & 5 & 1 \\
$\mathrm{~A}_{9}$ & 2 & 1 & 6 & 3 & 4 & 5 \\
$\mathrm{~A}_{10}$ & 3 & 4 & 5 & 2 & 6 & 1 \\
$\mathrm{~A}_{11}$ & 4 & 6 & 3 & 1 & 5 & 2 \\
$\mathrm{~B}_{1}$ & 2 & 4 & 5 & 3 & 6 & 1 \\
$\mathrm{~B}_{2}$ & 2 & 4 & 3 & 1 & 6 & 5 \\
$\mathrm{~B}_{3}$ & 2 & 3 & 1 & 4 & 5 & 6 \\
$\mathrm{~B}_{4}$ & 1 & 3 & 2 & 4 & 5 & 6 \\
$\mathrm{~B}_{5}$ & 2 & 3 & 1 & 4 & 5 & 6 \\
$\mathrm{~B}_{6}$ & 1 & 2 & 3 & 4 & 6 & 5 \\
Total of positions & 38 & 56 & 65 & 48 & 87 & 59 \\
Rank of the region & 1 & 3 & 5 & 2 & 6 & 4 \\
\hline
\end{tabular}

Note: SR - The Stavropol Region; RNO - the Republic of North Ossetia-Alania; KCR - the Karachayevo-Cherkessian Republic; KBD - the Kabardino-Balkarian Republic; RI - the Republic of Ingushetia; $\mathrm{RD}$ - the Republic of Dagestan. Remarks: no reliable official data on the Chechen Republic are available.

For the final typology we used a classification model of regions segmentation, which allows rating the subjects by the level of development of the banking industry and the intensity of its interaction with the real sector of 
economy of territories, promotes linguistic interpretation and economic characterization of the obtained polar areas, determines the consistency of the built typology with several indicative parameters.

As a result, we singled out five typological groups: ideal, well-developed, moderately developed, underdeveloped, depressed (Table 2).

Table 2. Anamorphic typological allocation of groups of regions by the level of development of the banking industry and the intensity of its interaction with the real sector of the economy of territories

\begin{tabular}{|c|c|c|c|}
\hline \multicolumn{2}{|c|}{$\begin{array}{l}\text { Interval values of } \\
\text { the group }\end{array}$} & \multirow[t]{2}{*}{$\begin{array}{l}\text { Name of the typological } \\
\text { group / regions placed in } \\
\text { the group }\end{array}$} & \multirow{2}{*}{$\begin{array}{l}\begin{array}{l}\text { Linguistic description of the economic interpretation of the typological } \\
\text { group }\end{array} \\
\text { Favorable infrastructure-institutional environment for establishment of } \\
\text { regional banks, interregional bank capital inflow, with the share of } \\
\text { sub-federal banking structures' participation in the formation of the total } \\
\text { assets more than } 50 \% \text {. The interaction of the non-financial sector and the } \\
\text { banking industry takes place with a significant effect that provides the } \\
\text { most positive impact on the formation of GRP. }\end{array}$} \\
\hline I & $\begin{array}{l}\text { Between } \\
17 \text { and } 31\end{array}$ & & \\
\hline II & $\begin{array}{c}\text { Between } \\
31 \text { and } 45\end{array}$ & $\begin{array}{c}\text { Developed } \\
\text { (the Stavropol Region) }\end{array}$ & $\begin{array}{l}\text { Small number of regional banks, but a well-developed branch network of } \\
\text { nonresident banks. Credit institutions of the region possess about } 40 \% \text { of } \\
\text { total assets. The interaction of the non-financial sector and the banking } \\
\text { industry takes place in the context of meeting the best interests of both } \\
\text { sides of the interaction. }\end{array}$ \\
\hline III & $\begin{array}{l}\text { Between } \\
45 \text { and } 59\end{array}$ & $\begin{array}{c}\text { Moderately developed } \\
\text { (the } \\
\text { Kabardino-Balkarian } \\
\text { Republic, the Republic } \\
\text { of North Ossetia-Alania, } \\
\text { the Republic of } \\
\text { Dagestan) }\end{array}$ & $\begin{array}{l}\text { Average number of regional banks and their branches, uneven } \\
\text { development of the branch network of credit institutions from other } \\
\text { regions, and the } 30 \% \text { share of assets of regional banks in the total assets } \\
\text { of the banking system. The interaction of the non-financial sector and the } \\
\text { banking industry is characterized by a lack of demand for bank capital, } \\
\text { and the medium level of investment attractiveness of the area. }\end{array}$ \\
\hline IV & $\begin{array}{l}\text { Between } \\
59 \text { and } 73\end{array}$ & $\begin{array}{c}\text { Underdeveloped (the } \\
\text { Karachayevo-Cherkessian } \\
\text { Republic) }\end{array}$ & $\begin{array}{l}\text { The parity of regional credit institutions and their offices and branches of } \\
\text { nonresident banks. Assets of regional banks account for } 14-22 \% \text { of total } \\
\text { assets. Poor development of the real sector of the economy does not } \\
\text { allow the banking system to develop in full, which in general has adverse } \\
\text { impact on the rate of GRP formation. }\end{array}$ \\
\hline V & $\begin{array}{l}\text { Between } \\
73 \text { and } 87\end{array}$ & $\begin{array}{l}\text { Depressive } \\
\text { (the Republic of } \\
\text { Ingushetia) }\end{array}$ & $\begin{array}{l}\text { Outflow of capital from the region's banking presence, inertness at } \\
\text { creating own regional banks, and less than } 10 \% \text { share of the assets of } \\
\text { regional banks. Interaction of the non-financial sector and the banking } \\
\text { industry of the economy are characterized by mutual antagonism and } \\
\text { unacceptability of the conditions of the parties' interaction. }\end{array}$ \\
\hline
\end{tabular}

\subsection{Formulation of Target-Oriented Recommendations to Address Interregional Differentiation}

In the current circumstances, the most effective mechanism for regulation of processes to reduce regional disparities in terms of development of the banking industry and its interaction with the real sector is the target-oriented approach. Taking this into account, the conceptual framework of the program of development of the banking industry in the lagging regions and improvement of the efficiency of its interaction with the real sector of the regional economy is the block-structured algorithm for the activities of the state (local) authorities, which determines:

- The common problems of the region;

- The urgent issues of development of the regional economy's banking industry;

- Determination of the priorities at supporting the real sector of the economy;

- The existing problems of territorial asymmetry in the development of polar zones, characterizing the intensity and nature of the interaction between the banking and real sectors in the context of their impact on the development of the region;

- The mechanism of solution of the tasks of changing the external factor environment of operation and development of the banking and real sectors of the regional economy; 
- Determination of the total of correlated and coordinated measures on solution of the tasks of development of the banking and real sectors of the regional economy.

The proposed program of reducing the differentiation of regions by the level of development of the banking industry of the economy and the efficiency of its interaction with the real sector is an instrument, through which the sub-federal authorities can ensure the focus, coordination, and effectiveness of the program events. (Morozov, 2007)

To ensure achievement of strategic targets, the program should be built in accordance with a number of principles: relevance, predictability, efficient resource use, realism, comprehensive approach, controllability and manageability, adaptability to specific characteristics of the region.

Relevance is the property of the program to be focused on solving the most important problems of the region development, in part of ensuring effective interaction of the non-financial sector and the banking industry of the regional economy.

Predictability is the property of the program to take into account in its targets and planned activities not only the retrospective trends and the trends of the real state of the regulated community, but also the forecasting trends in the development of the non-financial sector and the banking industry of the regional economy.

Efficient use of resources is the property of the program to allocate and reallocate available financial resources on a consolidated basis, with the priority of the goals to ensure the maximum social and economic benefits for the region.

Realism is the property of the program to ensure consistency between the planned results and the capacity necessary for their achievement.

Comprehensive approach is the property of the program to provide variation of the tooling required for achieving the priorities of regional development.

Controllability and manageability are the properties of the program to arrange feedback between the executors and their target audience on the issues of achievement of the goals by monitoring of the results obtained based on analytical information.

This list is not a limiting one and covers the main conceptual provisions on the form of program documents of the regional level of management. At the same time, development of programs without considering any of these principles will lead to mismatch of the expected and obtained results, violation of implementation terms, and overall reduction in socio-economic efficiency.

In the developed program, through implementation of a comprehensive set of program measures on improvement of the efficiency of interaction of the non-financial sector and the banking industry of the regional economy, the main implemented actions should be focused on initiating the processes of functional changes in the structure of the non-financial sector and the banking industry through the changes in the exogenous environment of their interaction. (Kugaev, 2000; Novoselov, 2007)

After determining the parameters of the exogenous environment change, it is to be revealed, which sectors should implement structural reforms providing particular details in the context of the priority lines:

1. Measures on the development of the banking industry of the region's economy;

2. Measures on the development of the real sector of the region's economy;

3. Measures on the development of the organizational and economic mechanism of interaction between the non-financial sector and the banking industry of the region's economy.

Within the framework of these lines, we highlighted several vectors of support and regulation, each of which depending on the actual state of development of the region can be identified as a priority one:

1. Regulatory and legal support;

2. Financial and credit support to the real sector of the regional economy (Tavasiev, 2005);

3. Support for the creation and development of the physical infrastructure;

4. Support of the development of new forms of lending to the real sector of the regional economy;

5. Support of the development of the personnel reserve in the non-financial sector and the banking industry;

6. Information and consulting support;

7. Promotion of interregional activities and access to interregional markets;

8. Promotion of the development of non-governmental infrastructure supporting the real sector of the regional economy; 
5.3 education and training of municipal employees involved in the development of the real sector of the economy

6. Information and consulting support

6.1 publication of informative and reference materials, recommendations in the form of business ideas for the real sector of the economy

6.2 organization and holding of interregional exhibitions, seminars, and meetings;

6.3 arrangement of coverage for the experience of interaction of the non-financial sector and the banking industry of the economy by the local mass media

6.4 outsourcing of consultants

7. Assistance in interregional activities and access to interregional markets

7.1 arrangement of interregional job fairs and banking services fairs

7.2 conclusion of interregional agreements for development of investment attractiveness, business stimulation.

7.3 development of interregional mono-product markets in order to ensure sales of enterprises of the real sector of the economy

8. Promotion of development of the non-governmental infrastructure of support of the real sector of the regional economy;

8.1 co-financing of establishment of funds and foundations supporting the real sector of the economy

8.2 involvement of higher educational institutions in improvement of economic education of top executives of the real sector of the economy

8.3 establishment of regional exhibition grounds

8.4 establishment of risk assessment infrastructure entities

Protection of interests of the interaction parties, measures to ensure their economic security and social protection, assistance in formation of favorable socio-psychological interaction environment

9.1 establishment of regional arbitration courts

9.2 anti-corruption measures

9.3 implementation of measures to ensure economic security of the region

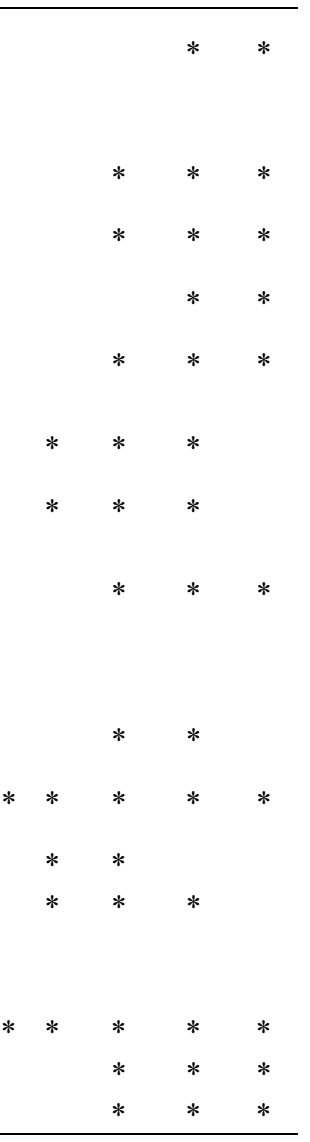

\subsection{Management of the Program Implementation}

The number and the morphological content of functional subprograms in the proposed concept depends on what lines of support were chosen at its development as the main ones and what personalized tooling sets of measures were formed for each of the lines.

An integral aspect of the development and implementation of these programs is the need to identify the main types of resources: the financial, material, technical, natural, and labor ones.

The main types of resources, the degree of endow of which is to be taken into account depending on the contents of the program, are the regional budget funds; the municipal budgets funds; extra-budgetary sources of financing; industrial areas, commercial and industrial premises; facilities; land resources; energy resources; labor and information resources.

In the development of these programs, the important point to our opinion is the formation of an optimal structure of the program management and monitoring of its implementation and outcomes. A formed management structure should perform the following functions:

- Development and approval of the program;

- Implementation of the program;

- Control over its implementation and evaluation of its results;

- Introduction of changes in the program.

Based on the necessity of combined application of the developed by us methodical and practical recommendations and features of the modern period of development of the regions, some time will be required, depending on the sequence of problems solution, considering which we find it appropriate to propose a logical model for phased increase in the efficiency of the development of the regional economy based on improvement of the mechanism of interaction between the non-financial sector and the banking industry (Figure 1). The measures proposed by us potentially are to be the regional component of the unified state policy on development of the non-financial sector and the banking industry of the economy, to contribute to the overall decline in economic differentiation of territories and to the economic, social, and political stability. 


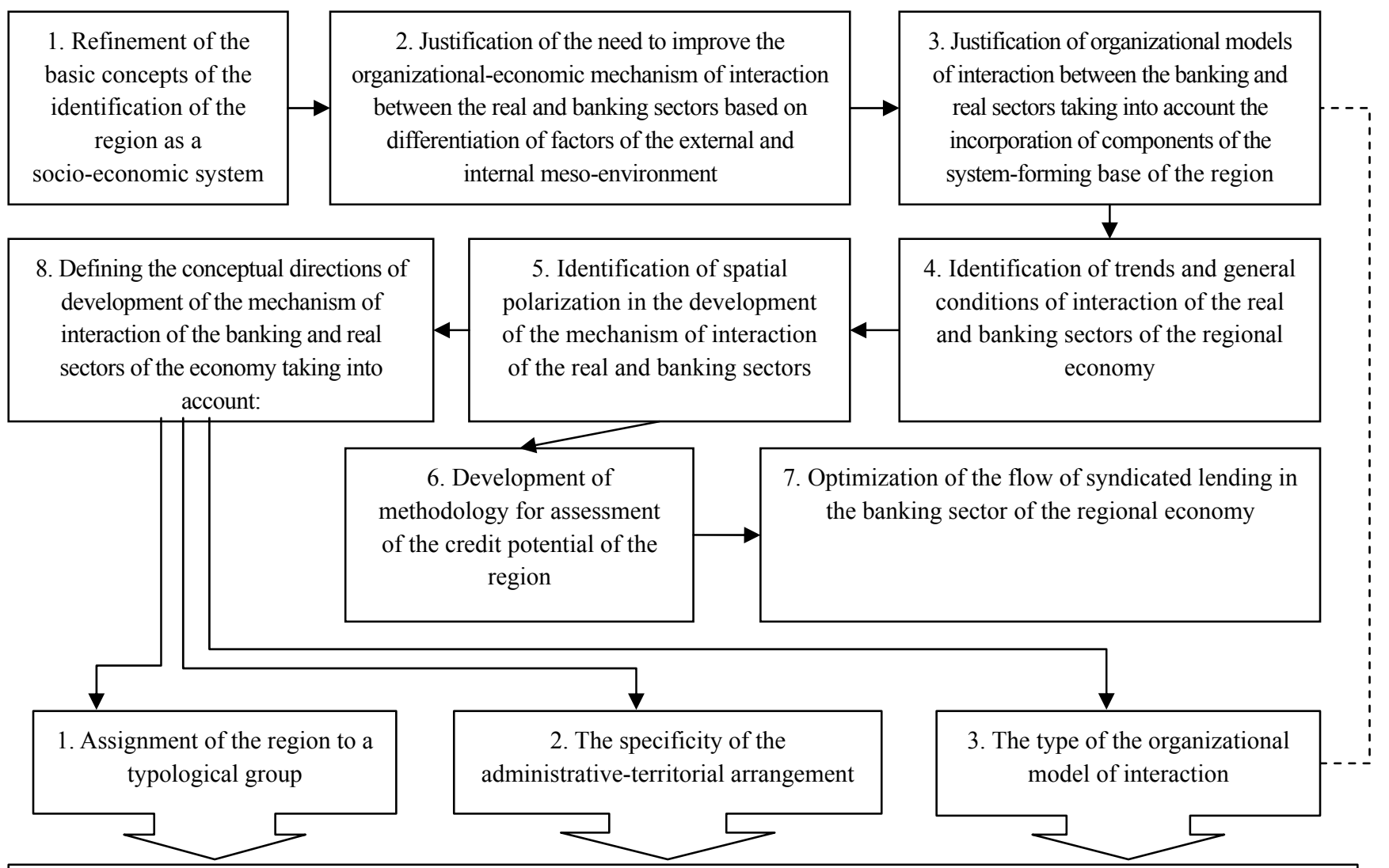

9. Development of a set of problem-targeted programs within the concept of phased increase in the efficiency of interaction of the real and banking sectors

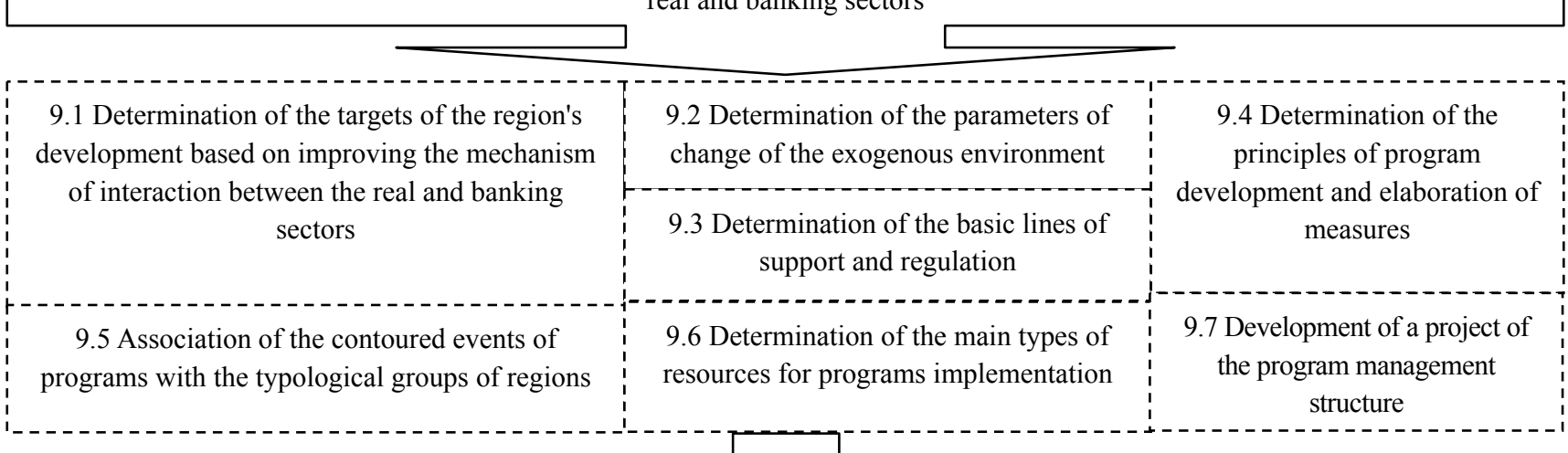

10. Monitoring of changes in criterial indicators as a result of implementation of program events

11. Application of the experience in other regions

Figure 1. The structural and logical model of decrease in the polar-symmetrical characteristics of regions by the level of development of the banking industry and the efficiency of its interaction with the real sector of the economy

\section{Discussion}

In the result of the performed study based on processing the extensive empirical-factual material and application of the formed methodical approach, we found out that the ideal typological group did not include any of the regions of the North Caucasus Federal District, which requires "elaboration of conceptual approaches to the development of both the banking industry and the mechanisms of increasing the intensity of its interaction with the real sector of the territories' economy". (Davis, 1999) 
The second typological group, which is characterized by a small number of regional banks, but an extensive branch network of nonresident banks, included one region of the NCFD - the Stavropol Region, which generally reflects the level of investment attractiveness of this territory and favorably influences on development of the local economy.

The third typological group is represented by three territories of the NCFD - the Kabardino-Balkarian Republic, the Republic of North Ossetia-Alania, and the Republic of Dagestan. These territories are characterized by the average number of regional banks and their branches, uneven development of the branch network of credit institutions from other regions, and low share of assets of regional banks in the total assets of the banking system.

The underdeveloped typological group included the Karachayevo-Cherkessian Republic, where functioning of the real sector of economy does not allow full development of the banking system, which in general has adverse impact on the rate of formation of the gross regional product.

The worst level of development of the banking industry and its interaction with the real economy territories is observed in the Republic of Ingushetia, which requires a comprehensive system policy to encourage the development of both the banking industry and enterprises, which will significantly complement the formation of the regional marginal product and increase the pace of socio-economic development of the territory.

The presented typology of regions by the level of development of the banking industry and the intensity of its interaction with the real sector of the economy in the regions of the North Caucasus Federal District may serve as visual aid for drawing cartograms, with the option to reduce the initial space of multidimensional data and keep the main topological and cluster properties effectively used for identifying and conducting an extensive genetic and structural-logical analysis and interpretation of the polar zones formed by the material criteria. It corresponds to the results of earlier studies (Edronova, 2007; Sarkisyants, 2006).

\section{Conclusions}

The performed study dedicated to identification of typological features of regions by the level of development of the banking industry and the intensity of its interaction with the real sector of the economy of territories showed that the economic space of subjects is heterogeneous by the substantive criterion.

The extent of development of the banking industry is at the same time the indicator of the economic situation of the region itself and the financial driver of this process, characterized by permanent, comprehensive, and chronotypic nature. (Ovchinnikova \& Grishaeva, 2008)

Identification of the extent of development of the banking industry and the intensity of its interaction with the real sector of the economy of territories allows in the context of the space-sectoral approaches to the management of territories and their sectors of the economy not only to assess the concentration characteristics of the economic space, but also to form relevant representation of the sub-federal banking systems in the context of regulative-control impact of the macroregulator of banks. We specified this heuristic problem in the study, in solidarity with recent studies (Penyugalova, 2008), as the necessity of development of efficient, comprehensible, and unified methodological support, allowing comprehensive systemic assessment of the degree of development of the banking industry and the intensity of its interaction with the real sector of the economy of territories. At that, we proved that such methodological support can be based on analytical and diagnostic capabilities of the methods of multivariate analysis allowing to perform comparative procedures with a high degree of objectivity. The methodological approaches developed in the study as well as their experimental testing on empirical-factual base of the regions of the North Caucasus Federal District allowed obtaining model representation of the typological singularities of the regions according to the degree of development of the banking industry and the intensity of its interaction with the real economy of territories with sufficient reliability and relevance, which is recommended to use at adjusting the regional economic policy in part of orientation to minimizing or compensating of the excessive "centripetal dynamics" (Mirokhina, 2013), which was implemented through the development of a model program of reduction of the polar-symmetric characteristics of the regional economy.

The prospects for further theoretical-methodological and practical-recommendatory researches are associated with improvement of the organizational-economic mechanism of development of the banking industry of the economy, formation of infrastructural support of the banking industry, development of methodology for monitoring changes in the qualitative and quantitative parameters of the banking industry.

\section{References}

Bobryshev, A. N., \& Kazakov, M. J. (2013). Rating territorial uneven development of economic entities traditionally agricultural regions (pp. 137-157). In the Proceedings of the 3rd International Scientific and 
Practical Conference Science and Society, SCIEURO, London.

Cipriani, M., \& Kaminsky, G. (2006). Volatility in International Financial Market Issuance: The Role of the Financial Center (p. 45). Cambridge: NBER Working Papers. http://dx.doi.org/10.3386/w12587

Davis, D. R., \& Weinstein, D. E. (1999). Economic geography and regional production structure: An empirical investigation. European Economic Review, 43, 379-407. http://dx.doi.org/10.1016/S0014-2921(98)00063-4

Edronova, V. N., \& Eliseev, N. P. (2007). Features of Russian Regional Banks. Finance and Credit, 24, 71.

Erlander, S. (1980). Optimal Spatial Interaction and the Gravity Model: Lecture Notes in Economics and Mathematical Systems - Berlin, Heidelberg, New York: Sprinder-Verlag, 173, 120.

Frankel J., \& Rose, A. (1996). Currency rashes in emerging markets: An Empirical Treatment. Journal of International Economics, 41, 351-366. http://dx.doi.org/10.1016/S0022-1996(96)01441-9

Kugaev, S. V., \& Kaltyrin, A. V. (2000). The contradictory nature of the functioning of the regional banking system. Business and Banks, 10(488), 1.

Mirokhina, A. A. (2013). Directions of development in the semi-periphery format compensation centripetal dynamics. Bulletin University (State University of Management), 18, 54-61.

Morozov, V. V. (2007). Investment framework and mechanism for the sustainable development of the regions. Region's Economy, 2, 120-134.

Novoselov, A. S. (2007). The market system in the region: reproductive aspect. Region: Economics and Sociology, $1,31$.

Ovchinnikova, O. P., \& Grishaeva, E. N. (2008). Coordination of the interests of the banking and industrial sectors to stimulate economic development in the region. Finance and Credit, 7, 17-25.

Pechonik, O. I., \& Butenko, V. N. (2006). Methodological approaches to the formation of the transition to sustainable development of credit institutions. Region's Economy, 1, 84-87.

Penyugalova, A. V., Tsitsiashvili, S. S., Platonov, Y. Y., \& Kravchishin, A. S. (2008). Development of the regional banking system in a market economy. Finance and Credit, 22, 2-10.

Postalyuk, M. P. (2006). Innovative relations in the economic system: theory, methodology, and practice (pp. 331). Kazan: Kazan University Publishing House.

Rykov, I. N., \& Fissenko, N. V. (2008). Assessment of the socio-economic development of the Stavropol Territory. Regional Economy: Theory and Practice, 31, 15-21.

Sachs, J., Tornell, A., \& Velasco, A. (1996). Financial Crises in Emerging Markets: The Lessons from 1995. Brookings Paper, 27(1), 147-199.

Sadkov, V. G., \& Ovchinnikov, O. P. (2006). Integrated development of the regions of Russia and the ways to overcome the asymmetry of credit in the development of municipalities. Finance and Credit, 21, 43-51.

Sarkisyants, A. G. (2006). Banks and the real sector at the present stage. Banking, 2, 6-12.

Shin, N. (2005). Peculiarities of regulation of investment processes at the regional level. Investments in Russia, 5 , 31-39.

Tavasiev, A., \& Mazurina, T. (2005). To assess the situation with the bank's lending to the real sector of the economy. Russian Economic Journal, 2, 30-38.

Tomilina, E. P., Glotova, I. I., \& Kuzmenko, I. P. (2013). Development of Integration Processes in the Traditional Sectors of Agriculture. Middle-East Journal of Scientific Research, 13(Socio-Economic Sciences and Humanities), 178-182.

Valliullin, H. H. (2009). Spatial mobility of the economies of Russia, USA and Canada. The United States and Canada: the Economy, Politics, Culture, 12, 47-62.

\section{Copyrights}

Copyright for this article is retained by the author(s), with first publication rights granted to the journal.

This is an open-access article distributed under the terms and conditions of the Creative Commons Attribution license (http://creativecommons.org/licenses/by/3.0/) 